\title{
Panentheistic Cosmopsychism: Swami Vivekananda's Sāṃkhya-Vedāntic Solution to the Hard Problem of Consciousness
}

\author{
Ayon Maharaj
}

This chapter provides the first detailed examination of the views on consciousness of Swami Vivekananda (1863-1902), the famous nineteenth-century Indian monk who introduced Hinduism and Vedānta to the West. First, I present Vivekananda's metaphysical framework of panentheistic cosmopsychism, according to which the sole reality is Divine Consciousness, which manifests as everything in the universe. As we will see, his panentheistic cosmopsychism combines elements from the classical Indian philosophical traditions of Sāmphya and Advaita Vedānta as well as the teachings of his guru Sri Ramakrishna (1836-1886). Then I reconstruct his sophisticated arguments in favor of panentheistic cosmopsychism. I argue that Vivekananda's panentheistic cosmopsychism, in light of its distinctive features and its potential philosophical advantages over rival theories of consciousness, deserves to be taken seriously by contemporary philosophers of mind and religion.

\footnotetext{
We now see that all the various forms of cosmic energy, such as matter, thought, force, intelligence and so forth, are simply the manifestations of that cosmic intelligence, or, as we shall call it henceforth, the Supreme Lord. Everything that you see, feel, or hear, the whole universe, is His creation, or to be a little more accurate, is His projection; or to be still more accurate, is the Lord Himself. It is He who is shining as the sun and the stars, He is the mother earth.... He is the speech that is uttered, He is the man who is talking. He is the audience that is here.... It is all He.

— Swami Vivekananda $(1896)^{1}$
}

\footnotetext{
* This essay presents, in a highly condensed form, the core argument of two chapters of my current book project, tentatively titled Swami Vivekananda's Vedāntic Cosmopolitanism.

1 CW2:211. Throughout this chapter, citations to Vivekananda's Complete Works (CW) follow this format: $\mathrm{CW}$,« volume number, page number.
} 


\section{Introduction}

Conscious experience is such a pervasive feature of our lives that we usually take it for granted. We experience, for instance, the delicious taste of tiramisu, the vivid colors of a rainbow, the sharp pain of a sprained ankle. What all these experiences have in common is an irreducibly subjective or qualitative character. As Thomas Nagel (1974) puts it, there is something it is like to be in any such experiential state. Recent philosophers have used technical terms like »qualia« and »phenomenal consciousness « to capture this subjective dimension of the experiential lives of human beings and (presumably) many other animals.

In spite of its familiarity, consciousness is notoriously difficult to explain. Philosophers throughout the world have puzzled over this ubiquitous feature of our everyday lives. What exactly is consciousness? What makes us conscious creatures rather than mere non-conscious automata? Does consciousness arise from physical states of the brain, and if so, how and why? The contemporary philosopher David Chalmers $(1995,1996)$ has made an influential distinction between »easy« and »hard« problems of consciousness. According to Chalmers, neuroscientists may very well be able to solve in the next century or two one of the »easy« problems of consciousness, such as the problem of pinpointing the neural correlates of particular conscious states. However, Chalmers argues that such a hypothetically complete and accurate science of physical correlations would still leave unanswered the one really hard problem of consciousness: namely, the problem of explaining why certain states of the brain are accompanied by, or give rise to, conscious experience. Similarly, Joseph Levine (1983) has argued that even if scientists are able to identify the physical correlates of conscious experiences, there still remains an »explanatory gap « between physical states and consciousness that needs to be bridged.

Philosophers have proposed a wide range of solutions to the hard problem of consciousness, including eliminativism, materialist reductionism, epiphenomenalist dualism, interactionist dualism, and mysterianism. For various reasons, many philosophers have not been satisfied with any of these theories of consciousness. As a result, a number of recent analytic philosophers of mind have begun to take seriously panpsychism, the apparently counterintuitive view that consciousness is present everywhere. ${ }^{2}$ There are two basic forms of panpsychism, depending on how one characterizes this fundamental form of consciousness. Micropsychism is the form of panpsychism according to which macro-level human and animal consciousness derives from the more

2 See, for instance, Nagel 1979, Brüntrup and Jaskolla 2017, Seager 2020, and Goff 2017 a. 
fundamental consciousness of micro-level entities. ${ }^{3}$ The most formidable problem facing micropsychist views is the »subject combination problem «一 the problem of explaining how micro-subjects can combine to form macro-level conscious subjects (Chalmers 2017).

In light of the subject combination problem, some contemporary philosophers have rejected micropsychism in favor of cosmopsychism, the view that human and animal consciousness derives from »cosmic consciousness, « the more fundamental consciousness of the universe as a whole. ${ }^{4}$ Clearly, cosmopsychism avoids the subject combination problem, since it explains human and animal consciousness in terms of cosmic consciousness rather than the consciousness of micro-level entities. However, cosmopsychist views still have to address the obverse problem - sometimes called the »derivation problem « (Nagasawa \& Wager 2017) or the »decombination problem «(Albahari 2020) of explaining how the conscious experiences of individual humans and animals derive from the singular consciousness of the cosmos as a whole.

While most contemporary philosophers have not considered non-western forms of panpsychism, some scholars have very recently begun to explore how ideas and arguments from Indian philosophical traditions — such as Vedānta, ${ }^{5}$ Yogācāra Buddhism, ${ }^{6}$ and Śaiva Nondualism ${ }^{7}$ — might be able to enrich contemporary debates about panpsychism. This chapter discusses the views of Swami Vivekananda (1863-1902), the famous nineteenth-century Indian monk who introduced Hinduism and Vedānta to the West. I argue that Vivekananda defends a distinctive form of cosmopsychism that has great contemporary relevance.

Section 2 presents Vivekananda's metaphysical framework of panentheistic cosmopsychism, according to which the sole reality is Divine Consciousness, which manifests as everything in the universe. As we will see, his panentheistic cosmopsychism combines elements from the classical Indian philosophical traditions of Sāmkhya and Advaita Vedānta as well as the teachings of his guru Sri Ramakrishna (1836-1886). Section 3 reconstructs Vivekananda's sophisticated arguments in favor of panentheistic cosmopsychism. I argue that his panentheistic cosmopsychism, in light of its distinctive features and its potential philosophical advantages over rival theories of consciousness, deserves to be taken seriously by contemporary philosophers.

3 For this definition of micropsychism, see Goff 2017b.

4 See, for instance, Shani 2015, Shani 2018, and Nagasawa and Wager 2017.

5 Gasparri 2019, Albahari 2020, and Vaidya 2020.

6 Duckworth 2017.

7 Biernacki 2016a,b. 


\section{Vivekananda's Sāṃkhya-Vedāntic Framework of Panentheistic Cosmopsychism}

In his approach to consciousness, Vivekananda takes his initial bearings from the classical Indian philosophical tradition of Sāṃkhya. Sāṃkhya upholds a metaphysical dualism between two fundamental entities, the eternal conscious Puruṣa (Spirit or Self) and the insentient Prakṛti (Primordial Nature). According to Sāṃkhya, insentient Prakṛti is the material cause of all creation, which first becomes intellect or will (mahat/buddhi), which itself becomes the ego-sense (ahamkāra), which in turn evolves into mind (manas), the five sense-capacities (buddhindriyas), the five action-capacities (karmendriyas), and the five subtle elements (tanmätras), and these tanmätras themselves evolve into the five gross elements (mahäbhütas). Sāmkhyans claim that all these twenty-four cosmic principles (tattvas) exist for the sake of the conscious Purușa, which is entirely separate from nature.

The English word »mind « corresponds to what Sāṃkhya philosophers call the »internal organ « (antahkarana), which comprises the intellect/will (buddhi), ego-sense (ahamkāra), and mind (manas) in the narrower sense of the thinking faculty. It is important to note that in Sāmkhya philosophy, the internal organ is also the lingaśarīra or sūkșmaśarìra (the fine or subtle body), the reincarnating entity which inhabits different physical bodies (sthūlaśarìras) from one life to the next. Vivekananda explains the Sāṃkhyan doctrine of reincarnation as follows:

\footnotetext{
Each one of the Purushas is omnipresent; each one of us is omnipresent, but we can act only through the Linga Sharira, the fine body. The mind, the selfconsciousness, the organs, and the vital forces compose the fine body or sheath, what in Christian philosophy is called the spiritual body of man. It is this body that gets salvation, or punishment, or heaven, that incarnates and reincarnates, because we see from the very beginning that the going and the coming of the Purusha or soul are impossible. (CW2:455-56)
}

Sāmphya, then, upholds a three-tiered ontology of the self: the insentient grossly physical body (sthülaśarira), the insentient subtly physical body which reincarnates (lingaśarìra), and the conscious non-physical Spirit (Purușa). Moreover, Sāmkhya philosophers accept the existence of multiple Puruṣas, each corresponding to a different lingaśarìra.

Vivekananda explains the Sāmkhyan approach to consciousness as follows: »Mind, intelligence, will, and everything else is insentient. But they are all reflecting the sentiency, the >Chit< [Consciousness] of some being who is beyond all this, whom the Sankhya philosophers call >Purusha« $(C W 2: 450)$. Crucially, 
then, even the mind (antahkarana) is actually a subtle form of insentient matter, but it appears to be conscious because of the »light « of the Purusa behind it. As Vivekananda puts it, »By itself the mind has no light; but we see it reasons. Therefore there must be some one behind it, whose light is percolating through Mahat [cosmic consciousness]... and subsequent modifications, and this is what Kapila [the founder of Sāmkhya] calls the Purusha, the Self of the Vedantin ...«(CW2:455-56). Obviously, Vivekananda intends the »light« of the Purusa illuminating the mind to be understood in metaphorical terms. For a snapshot of the Sāṃkhyan dualist system, see Figure 1.

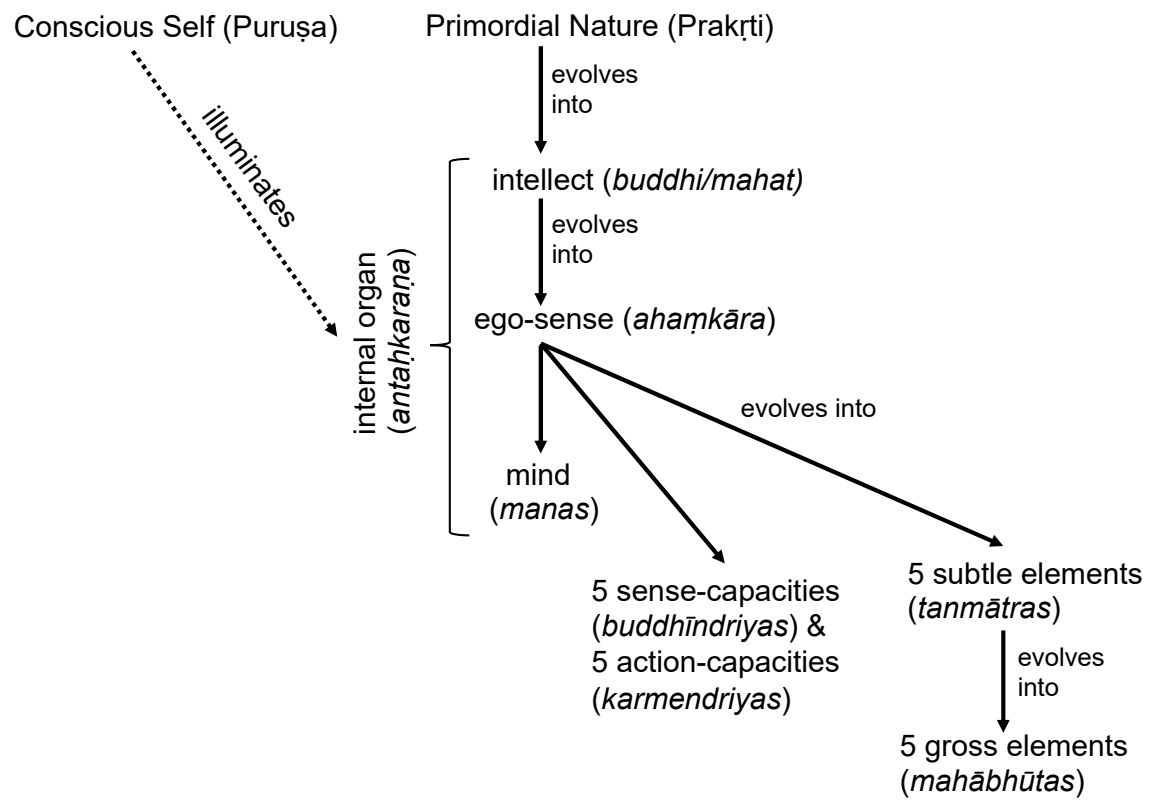

FIGURE 1 The Dualist System of Sāṃkhya

While Vivekananda accepts key elements from Sāṃkhyan philosophy, he also singles out for criticism three fundamental aspects of Sāmkhyan metaphysics: the doctrine of multiple Purușas, the doctrine that insentient Prakṛti is the source of all creation, and the metaphysical dualism between Puruṣa and Prakrti. Since I do not have the space to discuss his criticisms in detail, I will only summarize them here. Vivekananda's internal critique of the Sāmkhyan doctrine of multiple Puruṣas takes off from the Sāmkhyan premise that the Purusa is both omnipresent and infinite (CW2:46o-61). He argues that the notion of multiple infinites is incoherent, since the infinites would limit one another, thereby becoming finite. Hence, if the Purușa is truly infinite, it can 
only be one rather than multiple. For Vivekananda, then, the Sāṃkhyan doctrine of the infinitude of Purușa, when pushed to its logical conclusion, entails that there is only one Puruṣa — namely, the impersonal (nirguna) nondual Brahman of Advaita Vedānta.

Vivekananda also criticizes Sāmphyan atheism by presenting two main arguments for positing God (iśvara) as the efficient and material cause of all creation (CW2:46o). His first objection is based on the Sāmkhyan view that the macrocosm is reflected in the microcosm, so that each of the cosmic principles has its individual counterpart. ${ }^{8}$ For instance, according to Sāmkhya, while mahat is the universal or cosmic intellect, buddhi is its counterpart at the individual level. Vivekananda now argues as follows. If Sāmphya holds that all the individual manifestations of Prakrti exist for the sake of an individual Purușa, then it should also hold that all the cosmic manifestations of Prakrti exist for the sake of a universal Puruṣa as their »ruler and governor.« This universal Puruṣa, he claims, is none other than God (iśvara).

Vivekananda's second argument in favor of adding iśvara to the Sāṃkhyan system targets its doctrine of insentient Prakṛti ( $\left.\mathrm{CW}_{3}: 6-7\right)$. According to Vivekananda, Sāṃkhya posits both Puruṣa and Prakṛti as absolutes, so if the absolute Purușa is omnipresent and beyond time, space, and causation, then the absolute Prakrti must also be omnipresent and beyond time, space, and causation. In that case, however, there would be no »change or manifestation, « since Prakrti would be beyond nature altogether and unable to interact with it. He also makes an independent argument that it is impossible to have »two absolutes.« He seems to have in mind here his argument—mentioned earlierthat the notion of multiple infinite Purușas is incoherent, since they would limit each other. Similarly, two absolutes would limit each other and thereby lose their absolute status. To avoid this difficulty, we must posit a universal Puruṣa-God or iśvira - at the basis of Prakṛti.

Finally, Vivekananda argues that we should reject the spirit-matter dualism of Sāṃkhya in favor of a Vedāntic panentheism:

Beyond this Prakriti, and eternally separate from it, is the Purusha, the soul of the Sankhya which is without attributes and omnipresent. The Purusha is not the doer but the witness. The illustration of the crystal is used to explain the Purusha. The latter is said to be like a crystal without any colour, before which different colours are placed, and then it seems to be coloured by the colours before it, but in reality it is not. The Vedantists reject the Sankhya ideas of the soul and nature. They claim that between them there is a huge gulf to be bridged over.

8 Hence, as Larson (1969: 176-200) notes, Sāṃkhyan cosmology doubles as a psychology of the individual soul. 
On the one hand the Sankhya system comes to nature, and then at once it has to jump over to the other side and come to the soul, which is entirely separate from nature. How can these different colours, as the Sankhya calls them, be able to act on that soul which by its nature is colourless? So the Vedantists, from the very first affirm that this soul and this nature are one.... The idea of the Advaitists is to generalise the whole universe into one-that something which is really the whole of this universe. And they claim that this whole universe is one, that it is one Being manifesting itself in all these various forms. They admit that what the Sankhya calls nature exists, but say that nature is God. It is this Being, the Sat, which has become converted into all this - the universe, man, soul, and everything that exists. (CW1:361-62)

Vivekananda argues, rather swiftly, that the »huge gulf« Sāmkhya posits between Puruṣa and Prakṛti makes it impossible for Prakṛti to interact in any way with Puruṣa. Hence, he claims that the Vedāntic view that Puruṣa and Prakṛti »are one « is more logically sound than Sāmkhyan dualism. On this basis, he defends the panentheistic view that God, the sole Reality, has become everything in the universe.

According to Vivekananda, then, these three fundamental problems internal to Sāṃkyan metaphysics necessitate a transition from soul-matter dualism to spiritual monism. In particular, he defends a Vedāntic panentheism which incorporates key aspects of Sāṃkhyan metaphysics while also correcting for the latter's deficiencies and lacunae. It is crucial to note that Vivekananda's Vedāntic panentheism is based not on Śankara's world-denying philosophy of Advaita Vedānta but on the world-affirming Advaitic philosophy of his guru Sri Ramakrishna.

Sri Ramakrishna's views on consciousness are grounded in his philosophy of Vijñāna Vedānta, which I explain in detail in the first chapter of my book Infinite Paths to Infinite Reality (Maharaj 2018). Sri Ramakrishna makes a key distinction between two fundamental stages of spiritual realization

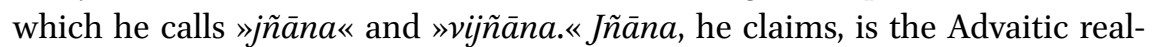
ization of one's true essence as the impersonal nondual Brahman, which is »immovable, immutable, inactive, and of the nature of Pure Consciousness [bodha-svarūpa] «(Gupta 1992: 430). ${ }^{9}$ The jĩāni feels that Brahman alone is real and that everything else is unreal. However, Sri Ramakrishna maintains that some rare souls, even after attaining brahmajñanna, can go on to attain the even greater state of vijñāna, a more intimate and expansive realization of God as the impersonal-personal Infinite Reality which has become everything in the universe. According to Sri Ramakrishna, »The vijñanni sees that the Reality which is impersonal [nirguna] is also personal [saguña]«(Gupta 1992: 104).

9 For the original Bengali, see Gupta 2010 (1897-1932). 
Hence, while the Advaitic jñānī dismisses Śakti (the personal God) as unreal, the vijñāni realizes that »Brahman and Śakti are inseparable« (Gupta 1992: 550; translation modified). Moreover, while the jũāni dismisses the world as unreal, the vijñāni looks upon the world as a real manifestation of God. As Sri Ramakrishna puts it, »God, as Consciousness [caitanya], has become the entire universe of the living and non-living« (Gupta 1992: 300).

Sri Ramakrishna explicitly states that he himself attained this panentheistic realization of vijñana:

Why should the universe be unreal? That is a speculation of the philosophers. After realizing God, one sees that it is God Herself who has become the universe and all living beings. The Divine Mother revealed to me in the Kāli temple that it was She who had become everything. She showed me that everything was Divine Consciousness [sab cinmaya]. The Image was Consciousness, the altar was Consciousness, the water vessels were Consciousness, the doorsill was Consciousness, the marble floor was Consciousness-all was Consciousness. I found everything inside the room soaked, as it were, in Bliss-the Bliss of Saccidānanda. I saw a wicked man in front of the Kālī temple; but in him also I saw the Śakti of the Divine Mother vibrating. That was why I fed a cat with the food that was to be offered to the Divine Mother. I clearly perceived that the Divine Mother Herself had become everything — even the cat... . After realizing God, one sees all this aright— that it is She who has become the universe, living beings, and the twenty-four cosmic principles. (Gupta 1992: 345)

In contemporary philosophical terms, we can say that Sri Ramakrishna's mystical experience of vijñana led him to accept a panentheistic form of cosmopsychism, according to which everything in the universe is one and the same Divine Consciousness manifesting in various forms. He specifically emphasizes that this Divine Consciousness is present not only in sentient creatures like cats and human beings but also in insentient things like water vessels and marble floors. Sri Ramakrishna considered his panentheistic worldview to be a world-inclusive form of Advaita. As he puts it, »The bhakta also has a realization of oneness [ekākār jñāna]; he sees that there is nothing but God. Instead of saying that the world is unreal like a dream, he says that God has become everything « (Gupta 1992: 700). Crucially, Sri Ramakrishna explicitly contrasted his world-inclusive Advaitic philosophy with the world-negating Advaitic philosophy of Śańkara and his followers.

Vivekananda, I will argue, addressed the hard problem of consciousness largely by developing and defending the vijñanna-based panentheistic cosmopsychism taught to him by Sri Ramakrishna. As we will see, Vivekananda frequently appealed to Advaita Vedānta in his efforts to explain and justify his panentheistic cosmopsychism, but we should always keep in mind that 
he followed Sri Ramakrishna in championing a world-inclusive Advaitic philosophy that conceives the world as a real manifestation of the impersonalpersonal God.

Crucially, Vivekananda's preferred nondual Vedāntic framework integrates within it all the elements of Sāmkhya philosophy which he takes to be valid. In particular, he fully accepts the Sāmkhyan doctrines that mind is a subtle form of matter and that conscious experience has a spiritual basis. He also accepts most of Sāmphyan cosmology, except that he equates Mahat with iśvara (and perhaps tacitly assimilates Sāṃkhyan Prakṛti to Mahat/iśvivara as well). He makes this explicit in an 1896 letter to his disciple E.T. Sturdy in which he sketches a diagram illustrating his Vedāntic cosmology:

I am working a good deal now upon the cosmology and eschatology of the Vedanta.... I intend to write a book later on in the form of questions and answers. The first chapter will be on cosmology, showing the harmony between Vedantic theories and modern science.

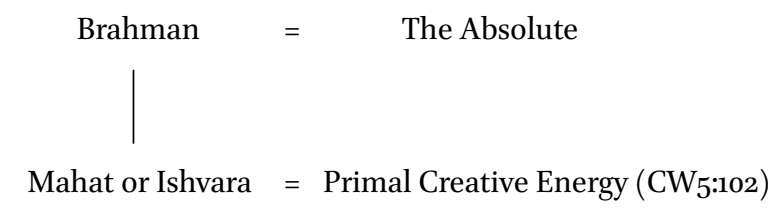

Unfortunately, he never found the time to write the book he had planned, so we will have to reconstruct his Vedāntic cosmology by drawing together various relevant passages in his work. For Vivekananda, Brahman is the impersonal (nirguna) nondual Absolute, and the vertical line indicates that it is inseparable from Mahat/Iśvara, the »Primal Creative Energy « which he also frequently refers to as »Shakti.« For instance, in his 1894 lecture »The Women of India,« he explains the inseparability of the impersonal Brahman and Śakti as follows:

[T]he central conception of Hindu philosophy is of the Absolute; that is the background of the universe. This Absolute Being, of whom we can predicate nothing, has Its powers spoken of as She - that is, the real personal God in India is She. This Shakti of the Brahman is always in the feminine gender. (CW9:195)

Vivekananda echoes here his guru Sri Ramakrishna's favorite teaching that »Brahman and Śakti are inseparable« (Gupta 1992: 550). Following Sri Ramakrishna, Vivekananda holds that while the impersonal nondual Brahman is utterly transcendent, Śakti-i.e. Mahat/İśvara—is the same Absolute in its dynamic form as the personal God who creates, preserves, and destroys the universe. 
Vivekananda's equation of İśvara with Mahat is highly significant, since it indicates how he integrates key aspects of the Sāmkhyan system into his own broader Vedāntic cosmology. In Vivekananda's hands, the insentient Mahat

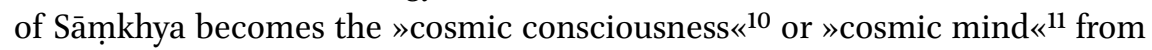
which everything in the universe derives:

What are you and I and all these souls? In our discussion of evolution and involution, we have seen that you and I must be part of the cosmic consciousness, cosmic life, cosmic mind, which got involved and we must complete the circle and go back to this cosmic intelligence which is God. This cosmic intelligence is what people call Lord, or God, or Christ, or Buddha, or Brahman, what the materialists perceive as force, and the agnostics as that infinite, inexpressible beyond; and we are all parts of that. (CW2:231)

In Vivekananda's Vedāntic cosmology, Mahat/İśvara manifests both as individual conscious souls (jivas) and as insentient minds (antahkaranas). As he puts it, »According to the Sankhya philosophy, the reactive state of the mind called Buddhi or intellect is the outcome, the change, or a certain manifestation of the Mahat or Cosmic Mind « (CW1:361). ${ }^{12}$ Vivekananda accepts unchanged the rest of the Sāmkhyan cosmology from buddhi down to the 5 mahābhutas (gross elements). He follows Sri Ramakrishna in championing a world-affirming Advaitic philosophy, according to which the sole reality is the impersonal-personal Infinite Divine Reality. We can now see that the personal aspect of the Infinite Reality is none other than Mahat/Ísara/Śakti, the »cosmic consciousness « which not only grounds, but actually is, everything in the universe. Ultimately, then, Vivekananda solves the hard problem of consciousness by appealing to a Sāṃkhya-Vedāntic framework of panentheistic cosmopsychism. While he accepts the Sāṃkyan view that the mind (antahkaraṇa) is insentient, he claims that all our conscious experiences are grounded not in the individual Purușa but in the all-pervasive Divine Consciousness. Figure 2 illustrates his panentheistic cosmopsychism in a nutshell.

10 Vivekananda equates Mahat with »cosmic consciousness « at least twice, in CW8:363 and CW2:231.

11 Vivekananda explicitly equates »Mahat« with the »Cosmic Mind « in several places, including CW1:360-1 and CW2:267.

12 CW1:361. I do not think Vivekananda means to imply that buddhi is a separate cosmic principle from Mahat. Rather, he follows Sāmkhya in taking buddhi to be the »individual Mahat« (CW1:250-51), the microcosmic counterpart to the macrocosmic Mahat. 


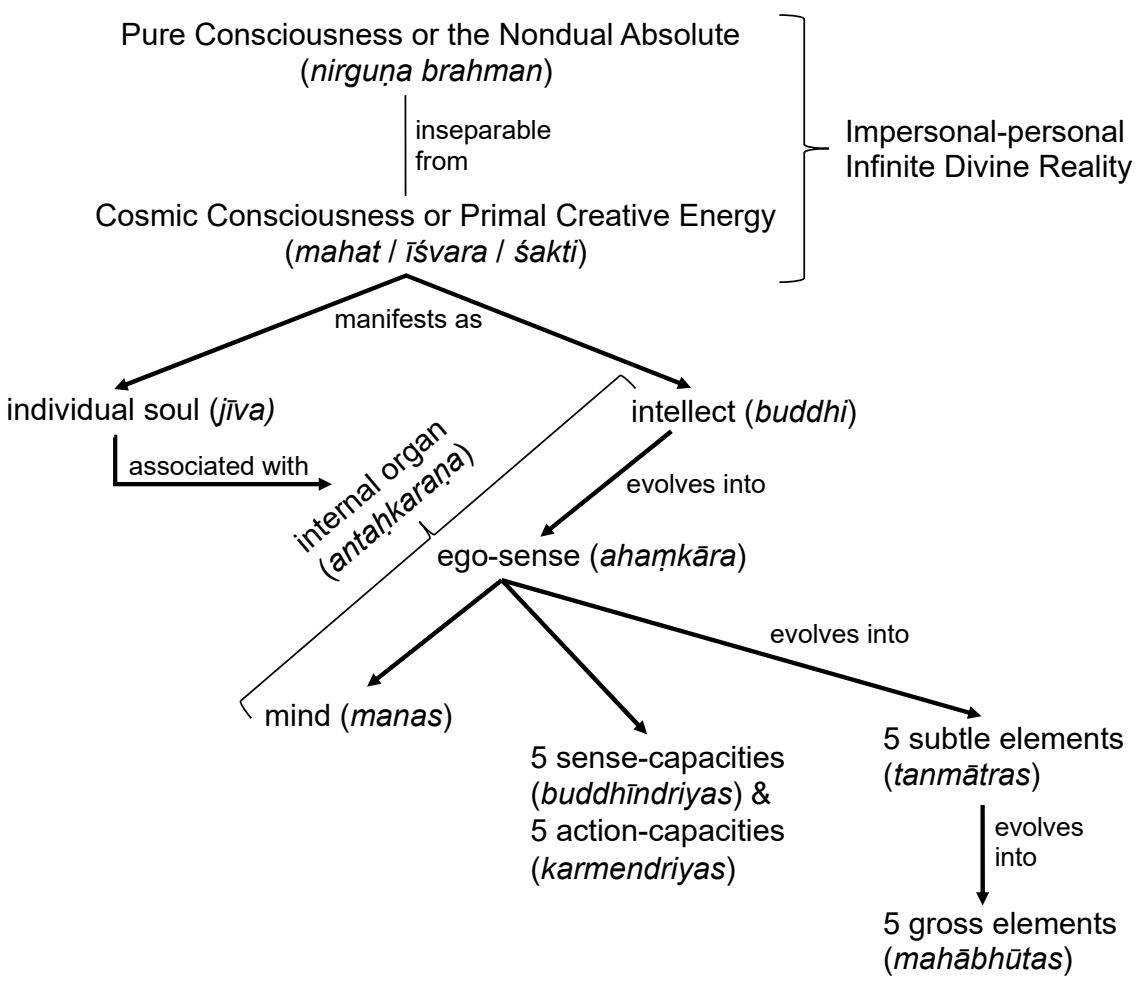

FIGURE 2 Vivekananda's Sāṃkhya-Vedāntic Framework of Panentheistic Cosmopsychism

As I discussed earlier, the most serious problem for contemporary cosmopsychists is the decombination problem: how does the single cosmic consciousness ground the conscious experiences of multiple individual subjects, each of whom has his or her own first-person perspective? In order to answer this question, most contemporary cosmopsychists have drawn upon Jonathan Schaffer's (2010) priority monism, the view that there exists only one basic entity, which grounds all other entities. Combining cosmopsychism with priority monism yields priority cosmopsychism, the view that cosmic consciousness is the only basic entity, which grounds all individual conscious experiences. Proponents of priority cosmopsychism offer differing accounts of how cosmic consciousness grounds the conscious experiences of individual subjects. ${ }^{13}$

I would argue that Vivekananda's panentheistic cosmopsychism is a distinctive form of priority cosmopsychism, which provides a unique account of the

13 See, for instance, Goff 2017a: 220-55, Shani 2015, Shani 2018, and Nagasawa \& Wager 2017. 
grounding relation. I would call Vivekananda's account of grounding "grounding by manifestation, « according to which $\mathrm{X}$ grounds by manifestation $\mathrm{Y}$ if and only if $\mathrm{Y}$ is a manifestation of $\mathrm{X}^{14}$ According to his panentheistic cosmopsychism, then, the Divine Cosmic Consciousness grounds the conscious experiences of individual subjects in the sense of manifesting as all of these individual subjects with their respective conscious experiences. According to Vivekananda, Mahat/Iśvara manifests as all the individuals souls (jivas), each of which has its own unique conscious perspective. My conscious experiences, rooted in my own first-person perspective, result from the association of my particular jiv $a$ with my particular antahkarana. Your conscious experiences, rooted in your different first-person perspective, result from the association of your jī $a$ with your antahkarana. Vivekananda's account of grounding by manifestation satisfies what Philip Goff calls the »free lunch constraint «-the constraint that any adequate theory of grounding must account for the apparent paradox that if $\mathrm{X}$ grounds $\mathrm{Y}$, then $(\mathrm{a}) \mathrm{Y}$ is nothing over and above $\mathrm{X}$, and yet (b) Y is not identical to X (Goff 2020:146). In Vivekananda's account of grounding by manifestation, ordinary conscious experience, as a manifestation of the Divine Cosmic Consciousness, is nothing over and above the Divine Cosmic Consciousness while not being identical to it.

How would Vivekananda respond to the decombination problem? Applied specifically to Vivekananda's panentheistic cosmopsychism, the decombination problem can be formulated as follows: how is it logically possible for God, with His own divine perspective, to manifest as various human beings, who enjoy their own different conscious perspectives? Since I provide a detailed reconstruction of Vivekananda's response to the decombination problem in the tenth chapter of my book in progress, I will only summarize his response here. According to Vivekananda's panentheistic cosmopsychism, Divine Consciousness is the sole reality. Through the individuating principle of $m \bar{a} y \bar{a}$, this nondual Divine Consciousness manifests as everything in the universe through a process of playful self-limitation or self-veiling (CW2:125-26). In ignorant people, the Divine Consciousness manifests as egoic consciousness. As a result, ignorant people remain unaware of their own divine nature, and their conscious perspectives are grounded in their identification with the body-mind complex and their consequent preoccupation with worldly thoughts and desires (CW6:474-75). Those who engage in spiritual practice can ascend to higher planes of consciousness through the awakening of the Kunḍalinī (CW4:237). Vivekananda would often appeal to the analogy of »veils« to convey that our true nature is Divine Consciousness and that the aim of all spiritual practice is

14 I borrow the structure of this formulation of grounding from Goff (2019). 
nothing but to remove the »veils « covering our divine nature. As he puts it in his lecture »The Real Nature of Man, «»Every good thought that you think or act upon is simply tearing the veil, as it were; and the purity, the Infinity, the God behind, manifests Itself more and more « (CW2:82). As we ascend to higher planes of consciousness, veil after veil covering the Divine Consciousness is removed, and our conscious perspective itself changes at each higher plane, until the Kunḍalinī finally rises to the sahasrāra, and we realize our true nature as the Divine Consciousness without any veils.

Hence, from Vivekananda's perspective, the conscious perspectives of various people are one and the same Divine Consciousness limited or »veiled « to varying degrees and in different ways, depending on their current plane of consciousness. Since the various planes of consciousness are mutually exclusive (CW3:20-21), our ignorant conscious perspectives and God's divine perspective are also mutually exclusive. So long as we enjoy our ignorant conscious perspectives, we do not, and cannot, share the perspective of Divine Consciousness. Conversely, when we realize our true nature as Divine Consciousness, we no longer have our ego-centered conscious perspectives. Crucially, then, God's divine perspective never coexists with our own limited conscious perspectives as ignorant human beings. Hence, I would argue that Vivekananda's account of grounding by manifestation provides a novel and elegant solution to the decombination problem that deserves to be taken seriously by contemporary philosophers.

If Vivekananda is right that we are nothing but different manifestations of God, why don't we all think of ourselves as God? Why don't we share God's first-person cosmic perspective rather than having our own individual firstperson perspectives? Vivekananda's Vedāntic answer is that we are deluded into thinking that we are autonomous individuals due to our preoccupation with our own ego and its selfish concerns and desires. As he puts it, »Man only remains hypnotised with the false idea of an ego. When this ghost is off from us, all dreams vanish, and then it is found that the one Self only exists from the highest Being to a blade of grass « (CW6:474-75). According to Vivekananda, by renouncing sense-pleasures and engaging in ethical and spiritual practices like meditation, unselfish service, and the worship of God, we can break our false identification with our ego and realize our true nature as God Himself:

There is only one Self in the universe, only One Existence, and that One Existence, when it passes through the forms of time, space, and causation, is called by different names, Buddhi, fine matter, gross matter, all mental and physical forms. Everything in the universe is that One, appearing in various forms.... You are the Infinite... . Therefore the idea that you are Mr. So-and-so can never be true; it is a day-dream. Know this and be free. This is the Advaita conclusion. (CW2:462) 
It is important to note here that Vivekananda's »Advaita conclusion « is based on the world-affirming Advaita taught to him by Sri Ramakrishna rather than the world-negating Advaita Vedānta of Śankkara and his followers. According to Śankkara's Advaita Vedānta, nondual Brahman alone is real and this entire universe is ultimately unreal. It may appear that Vivekananda endorses Śankara's Advaitic position when he says that our individuality is a »day-dream.« However, it is clear from the context that what he means is that our delusion consists in thinking that we are autonomous individuals; in reality, we are different manifestations of God Himself. Crucially, Vivekananda follows Sri Ramakrishna rather than Śankara in holding that God actually manifests as both deluded and enlightened people. Sri Ramakrishna makes this point explicitly in the following passage:

This world is the lil $\bar{a}$ [sportive play] of God... . God alone has become all this$m \bar{a} y \bar{a}$, the universe, living beings [jīivas], and the twenty-four cosmic principles.... It is God Himself who has become both vidya [Knowledge] and avidya [ignorance]. He remains deluded by the māya of avidyā. Again, with the help of the guru, He is cured by the māya of vidyā... The vijñanni sees that it is God who has become all this. (Gupta 436; translation modified)

For Sri Ramakrishna and Vivekananda, the omnipotent God playfully manifests as everything in the universe, including both deluded and enlightened people. Moreover, in contrast to Śankara, they hold that God's world-līla is impermanent but perfectly real. Hence, Vivekananda maintains that our ordinary conscious experiences are real manifestations of the Divine Cosmic Consciousness.

It is also important to note that Vivekananda's panentheistic cosmopsychism, in spite of its nondualism, preserves the Sāṃkhyan distinction between sentient and insentient entities. While Vivekananda maintains that everything in the universe - including both sentient creatures and insentient entities-is a manifestation of the same Divine Consciousness, he does not hold that everything is conscious in the sense of being mental or sentient. Rather, he holds the Sāmkhyan view that only entities with a mind (antahkarana) are sentient. Surendranath Dasgupta (1922: 241) succinctly explains why an antahkarana is necessary for conscious experience:

A question naturally arises, that if the knowledge forms [i.e. the antahkarana] are made up of [the same ${ }^{15}$ sort of stuff as the objective forms of matter are, why

15 Dasgupta's original phrasing is as follows: »... if the knowledge forms are made up of some sort of stuff as the objective forms of matter are....« Since this phrase is ungrammatical as it stands, I have supplied in brackets what I believe he meant. 
then should the puruṣa illuminate it [i.e. the antahkarana] and not external material objects. The answer that Sāmkhya gives is that the knowledge-complexes are certainly different from external objects in this, that they are far subtler and have a preponderance of a special quality of plasticity and translucence (sattva), which resembles the light of purușa, and is thus fit for reflecting and absorbing the light of the puruṣa.

In other words, a physical structure must be sufficiently subtle and translucent to reflect the light of the Purușa. Gross physical entities like stones are insentient because they lack the subtlety and translucency (sattva) necessary to reflect the light of the Puruṣa. Human beings, dogs, and bats, by contrast, are sentient because their minds (antahkaraṇas) are sufficiently subtle and translucent to reflect the light of their respective Purușas. Vivekananda fully accepts this Sāṃhyan view but replaces the individual Puruṣas of Sāṃhya with the single Divine Cosmic Consciousness. According to Vivekananda, only entities endowed with an antahkarana can be sentient because an antahkaraṇa is necessary to reflect the light of the all-pervasive Divine Consciousness.

\section{Vivekananda's Arguments for Panentheistic Cosmopsychism}

Even if Vivekananda's panentheistic cosmopsychism seems to be logically coherent and offers an arguably elegant account of ordinary conscious experience, why should we believe that it is a plausible metaphysical worldview? In numerous lectures, he presents arguments in support of the plausibility of panentheistic cosmopsychism. Unfortunately, since he never wrote the definitive book on Vedāntic philosophy that he had planned, there is no single place in his corpus where he works out these arguments systematically and in detail. Accordingly, in the remainder of this section, I will try to reconstruct his justification of panentheistic cosmopsychism by drawing upon his various lectures and writings. A good starting-point for this reconstruction is his lecture »The Cosmos: The Macrocosm, « delivered in New York on 19 January 1896, which contains his most detailed argument for panentheistic cosmopsychism. The relevant passage from the lecture is long but needs to be quoted in full, since it is a continuous piece of reasoning:

Next comes a very important question especially for modern times. We see that the finer forms develop slowly and slowly, and gradually become grosser and grosser. We have seen that the cause is the same as the effect, and the effect is only the cause in another form. Therefore this whole universe cannot be produced out of nothing. Nothing comes without a cause, and the cause is the effect in another form. 
Out of what has this universe been produced then? From a preceding fine universe. Out of what has men been produced? The preceding fine form. Out of what has the tree been produced? Out of the seed; the whole of the tree was there in the seed. It comes out and becomes manifest. So, the whole of this universe has been created out of this very universe existing in a minute form.... This coming out of the fine and becoming gross, simply changing the arrangements of its parts, as it were, is what in modern times [is] called evolution. This is very true, perfectly true; we see it in our lives. No rational man can possibly quarrel with these evolutionists. But we have to learn one thing more. We have to go one step further, and what is that? That every evolution is preceded by an involution.... The whole of this universe was present in the cosmic fine universe. The little cell, which becomes afterwards the man, was simply the involved man and becomes evolved as a man. If this is clear, we have no quarrel with the evolutionists, for we see that if they admit this step, instead of their destroying religion, they will be the greatest supporters of it.

We see then, that nothing can be created out of nothing.... The whole series of evolution beginning with the lowest manifestation of life and reaching up to the highest, the most perfect man, must have been the involution of something else. The question is: The involution of what? What was involved? God. The evolutionist will tell you that your idea that it was God is wrong. Why? Because you see God is intelligent, but we find that intelligence develops much later on in the course of evolution. It is in man and the higher animals that we find intelligence, but millions of years have passed in this world before this intelligence came. This objection of the evolutionists does not hold water, as we shall see by applying our theory. The tree comes out of the seed, goes back to the seed; the beginning and the end are the same. The earth comes out of its cause and returns to it. We know that if we can find the beginning we can find the end. E converso, if we find the end we can find the beginning. If that is so, take this whole evolutionary series, from the protoplasm at one end to the perfect man at the other, and this whole series is one life. In the end we find the perfect man, so in the beginning it must have been the same. Therefore, the protoplasm was the involution of the highest intelligence. You may not see it but that involved intelligence is what is uncoiling itself until it becomes manifested in the most perfect man. That can be mathematically demonstrated. If the law of conservation of energy is true, you cannot get anything out of a machine unless you put it in there first.... There cannot be added in the economy of this universe one particle of matter or one foot-pound of force, nor can one particle of matter or one foot-pound of force be taken out. If that be the case, what is this intelligence? If it was not present in the protoplasm, it must have come all of a sudden, something coming out of nothing, which is absurd. It, therefore, follows absolutely that the perfect man, the free man, the God-man, who has gone beyond the laws of nature, and transcended everything, who has no more to go through this process of evolution, through birth and death, that man called the »Christ-man « by the Christians, and the »Buddha-man« by the Buddhists, and the »Free« by the Yogis - that perfect man who is at one end of the chain of evolution was involved in the cell of the protoplasm, which is at the other end of the same chain.

Applying the same reason to the whole of the universe, we see that intelligence must be the Lord of creation, the cause. What is the most evolved notion 
that man has of this universe? It is intelligence, the adjustment of part to part, the display of intelligence, of which the ancient design theory was an attempt at expression. The beginning was, therefore, intelligence. At the beginning that intelligence becomes involved, and in the end that intelligence gets evolved. The sum total of the intelligence displayed in the universe must, therefore, be the involved universal intelligence unfolding itself. This universal intelligence is what we call God. Call it by any other name, it is absolutely certain that in the beginning there is that Infinite cosmic intelligence. This cosmic intelligence gets involved, and it manifests, evolves itself, until it becomes the perfect man, the »Christ-man,« the »Buddha-man.«... This cosmic intelligence is what the theologians call God....

We now see that all the various forms of cosmic energy, such as matter, thought, force, intelligence and so forth, are simply the manifestations of that cosmic intelligence, or, as we shall call it henceforth, the Supreme Lord. Everything that you see, feel, or hear, the whole universe, is His creation, or to be a little more accurate, is His projection; or to be still more accurate, is the Lord Himself. It is He who is shining as the sun and the stars, He is the mother earth. He is the ocean Himself. He comes as gentle showers, He is the gentle air that we breathe in, and He it is who is working as force in the body. He is the speech that is uttered, He is the man who is talking. He is the audience that is here. He is the platform on which I stand, He is the light that enables me to see your faces. It is all He. He Himself is both the material and the efficient cause of this universe, and $\mathrm{He}$ it is that gets involved in the minute cell, and evolves at the other end and becomes God again. He it is that comes down and becomes the lowest atom, and slowly unfolding His nature, rejoins Himself. This is the mystery of the universe. »Thou art the man, Thou art the woman, Thou art the strong man walking in the pride of youth, Thou art the old man tottering on crutches, Thou art in everything. Thou art everything, O Lord.« This is the only solution of the Cosmos that satisfies the human intellect. (CW2:207-11) ${ }^{16}$

This passage contains Vivekananda's core argument for panentheistic cosmopsychism, though I believe there are key points in the argument where certain premises are implied or presupposed rather than explicitly stated. I will supply these missing premises by drawing on his statements and arguments in other lectures and writings. On my reconstruction, Vivekananda actually makes two independent but mutually supportive arguments, the first in support of panpsychism in general, and the second in support of panentheistic cosmopsychism in particular. I will now present and discuss each argument in turn. I take both his arguments to be abductive arguments (inferences to the best explanation), rather than deductive or inductive arguments.

16 Vivekananda makes a similar involution argument in numerous other places, including CW2:74, CW2:173, and CW8:362-63. 
Argument 1: Vivekananda's Involution Argument for Panpsychism

1. Doctrine of the Pre-existent Effect: If $c$ is the material cause of $e$, then $e$ must already be present in some form in $c$.

2. Denial of Materialist Reductionism: Consciousness is not identical to anything material, such as a brain state.

3. Denial of Emergentism: Consciousness could not have emerged from non-conscious matter at a certain point in the evolutionary process. ( from 1 and 2 )

4. Plausibility of Panpsychism: Therefore, it is reasonable to believe that consciousness is involved-that is, present in some form-even in primordial matter. (from 2 and 3 )

Premises 1 and 3, as well as the conclusion 4, are explicitly stated in the long passage cited above. I would argue that premise 2, though not explicitly stated in this passage, is presupposed here and explicitly stated elsewhere.

In the first paragraph of the long passage, Vivekananda states premise 1, the Sāmkhyan doctrine of the pre-existent effect (satkārya): »the effect is only the cause in another form.« According to Sāṃkhya, nothing new can ever be produced; rather, all effects are already present in another form in their respective material causes. The Sāṃkhya scholar Gerald James Larson (1969: 165) summarizes two of the main arguments Sāmkhyans provide in support of satkāryavāda: »First of all, non-being obviously can produce or do nothing. Second, the effect is made up of the same material as the cause, there being a difference only with respect to the appearance or modification of the material." Vivekananda reaffirms both of these Sāṃkhyan arguments for satkāryavāda. He echoes the first Sāmkhyan argument when he states that »nothing can be created out of nothing. « Later in the same paragraph, he makes this same point in a slightly different way when he says that the notion of »something coming out of nothing « is »absurd.« The intuition here is a powerful one: it just seems obvious that there must be a sufficient material cause for any existing entity. He provides three examples to make this intuition more plausible: this entire universe must have been produced from »a preceding fine universe «; human beings are produced from the "preceding fine form«; and a tree is produced from »the seed.«Vivekananda also echoes the second Sāṃkhyan argument for satkāryavāda: It is a matter of empirical fact that »the cause is the effect in another form. «If we examine the nature of any given effect, we will find that it is made of the same material as its material cause, only in a modified form.

In cosmopolitan fashion, Vivekananda then goes on to provide further support for the Sāmkhyan doctrine of satkārya by appealing to two modern Western scientific theories: namely, the doctrine of evolution and the law of 
the conservation of energy. As he puts it, »This coming out of the fine and becoming gross, simply changing the arrangements of its parts, as it were, is what in modern times [is] called evolution. This is very true, perfectly true... . « Significantly, Vivekananda defines the doctrine of evolution in very general terms as a continuous process that molds pre-existing properties into other forms. He argues that a logical consequence of this modern doctrine of evolution is that »every evolution is preceded by an involution. « That is, the modern scientific understanding of the evolutionary process implies satkāryavāda: since nothing truly novel can emerge through the evolutionary process, the evolved entity or property had to have been »involved «-that is, pre-existent in a latent form -in that from which it evolved. As Vivekananda puts it, »The little cell, which becomes afterwards the man, was simply the involved man and becomes evolved as a man.«

Vivekananda was familiar with the views of Charles Darwin, T.H. Huxley, and Herbert Spencer-all of whom defended various forms of the doctrine of evolution - and he often referred to »Darwin « and »Darwinism « in his lectures and writings. ${ }^{17}$ However, it is crucial to note that Vivekananda says nothing here about the mechanism of evolution. Indeed, in other places, he explicitly criticizes Darwin's preferred evolutionary mechanism of natural selection, arguing that while natural selection certainly operates in the »animal kingdom, « it cannot account for the moral and spiritual qualities of human beings $\left(\mathrm{CW}_{7}: 154\right) \cdot{ }^{18}$ Hence, the modern doctrine of evolution which Vivekananda endorses as "perfectly true« is only the very general one which holds that presently existing entities did not emerge suddenly or out of nothing but evolved gradually from earlier entities in which the presently existing entities were already present in a latent form. For Vivekananda, then, modern scientific evidence for the truth of evolution lends further support to the ancient Sāmphyan doctrine of satkärya. Vivekananda also supports premise 1 by appealing to the law of the conservation of energy, which holds that the total amount of energy in the universe remains constant and that this energy only changes forms and manifests in a variety of ways. If this law is true, he argues, then nothing new can come into existence; rather, what exists now is only a »change« or »manifestation « of what existed previously.

Vivekananda explicitly defends premise 2 (the denial of materialist reductionism) in his lecture »The Science of Yoga « delivered in California in 1900:

17 See, for instance, $\mathrm{CW}_{7: 15^{2-5}}$ and CW6:40.

18 For discussion of Vivekananda's criticisms of Darwinian evolution, see Killingley 1990 and Brown 2012: 131-54. 
The mind cannot be analysed by any external machine. Supposing you could look into my brain while I am thinking, you would only see certain molecules interchanged. You could not see thought, consciousness, ideas, images. You would simply see the mass of vibrations - chemical and physical changes. From this example we see that this sort of analysis would not do....

External analysis will go to the brain and find physical and chemical changes. It would never succeed [in answering the questions]: What is the consciousness? What is your imagination? Where does this vast mass of ideas you have come from, and where do they go? We cannot deny them. They are facts. I never saw my own brain. I have to take for granted I have one. But man can never deny his own conscious imagination. $\left(\mathrm{CW}_{7}: 431-2\right)$

Here, Vivekananda rejects two strategies for explaining consciousness that are still being actively discussed by contemporary philosophers of mind - namely, materialist reductionism and eliminativism. While materialist reductionism seeks to explain consciousness in terms of physical states of the brain, eliminativism goes to the extreme of claiming that first-person consciousness does not even exist. Against eliminativism, Vivekananda argues that first-person conscious experiences are »facts « that cannot be denied. Against materialist reductionism, Vivekananda claims that through the methods of physical science, we might be able to demonstrate, at best, that certain »physical and chemical changes « in the brain correspond to certain states of consciousness. However, he argues that »[t]he mind cannot be analysed by any external machine, « because any such objective scientific analysis of the brain would require abandoning the subjective point of view with which conscious experiences are essentially connected $\left(\mathrm{CW}_{7}: 431\right)$. Therefore, he concludes that consciousness cannot be identical to anything material, such as a particular brain state. He thereby anticipates Nagel's argument against reductionism in his influential article »What Is It Like to Be a Bat?« (1974). As Nagel (1974: 437) puts it, »every subjective phenomenon is essentially connected with a single point of view, and it seems inevitable that an objective, physical theory will abandon that point of view.« Vivekananda can also be seen as anticipating Chalmers's distinction between »easy« and »hard « problems of consciousness, since Vivekananda distinguishes the easy problem of identifying the neural correlates of consciousness from the hard problem of explaining the nature of consciousness and how and why it is correlated with certain brain states.

Now we can come back to Vivekananda's involution argument for panpsychism. The reason I include his denial of materialist reductionism as the second premise of his involution argument will be obvious once we go on to discuss premise 3 . If materialist reductionism holds, then consciousness would be identical to a brain state, and there would be no difficulty in explaining how consciousness - taken to be wholly physical-could have evolved from 
non-conscious matter at a certain point in the evolutionary process. Hence, although Vivekananda does not explicitly state premise 2 in the context of his involution argument for panpsychism, he nonetheless presupposes this premise.

Vivekananda defends premise 3 (the denial of emergentism) on the basis of the first two premises. As Vivekananda himself notes, many of his contemporaries subscribed to emergentism, the view that consciousness emerged at a late stage in evolutionary history. He defines the emergentist position as follows: »It is in man and the higher animals that we find intelligence, but millions of years have passed in this world before this intelligence came." Vivekananda refutes emergentism by appealing to the doctrine of the preexistent effect (premise 1): »[W]hat is this intelligence? If it was not present in the protoplasm, it must have come all of a sudden, something coming out of nothing, which is absurd. « According to Vivekananda, the emergentist view that conscious intelligence arose from non-conscious matter at a certain point in our evolutionary history is »absurd « because it is tantamount to holding that something can come from nothing, a position that is ruled out by premise 1. Since consciousness is distinct from matter (premise 2) and something cannot come from nothing, consciousness could not possibly have emerged from non-conscious matter.

In the statement just cited in which Vivekananda refutes emergentism, he also introduces the conclusion 4: the only way to avoid the »absurd « doctrine of emergentism is to assume that conscious intelligence was already "present in the protoplasm. «In other words, he believes that premise 3 makes it reasonable to accept panpsychism, the view that consciousness is present in everything. Just as the entire tree was »involved «—-that is, present in a latent form-in the seed from which it grew, consciousness was involved, in the distant past, even in the most primitive forms of matter and life. As he puts it, the »perfect man ... was involved in the cell of the protoplasm.....

Vivekananda was not alone among his contemporaries in defending panpsychism. In fact, both W.K. Clifford (1845-1879) and William James (1842-1910) presented similar arguments for panpsychism. Like Vivekananda, James argued in his Principles of Psychology (1950 [189o]: 149), »If evolution is to work smoothly, consciousness in some shape must have been present at the very origin of things. « Likewise, Clifford (1874: 60-1) argued that the »doctrine of evolution « rules out the possibility of emergentism - which would have amounted to an »enormous ... jump from one creature to another «-and claimed, therefore, that there is consciousness or protoconsciousness »even in the Amoeba.«Vivekananda may even have been aware of the pan(proto?)psychist views of Clifford or James. However, Vivekananda was unique among his contemporaries in arguing for panpsychism on the basis of the doctrine of the 
pre-existent effect (premise 1). For Vivekananda, since evolution presupposes material causation, it is an instantiation of the more general Sāṃkyan doctrine that every effect pre-exists in its material cause.

It is also worth noting that contemporary philosophers of mind like Thomas Nagel and Philip Goff have advanced so-called »genetic « arguments for panpsychism that are very similar to Vivekananda's involution argument. Recently, Nagel (2012: 14-15) has argued for panpsychism on the grounds that »evolutionary biology ... cannot account for the appearance of consciousness and of other phenomena that are not physically reducible.« Similarly, Goff (2013) defends a »sorites-style argument for panpsychism «based on the assumption of the truth of evolutionary theory. According to Goff (2017b), if we assume that emergentism is true and that consciousness does not admit of borderline cases, then »we will have to suppose that some utterly precise microlevel change - down to an exact arrangement of particles-marked the first appearance of consciousness..., and it is going to seem arbitrary that it was that utterly precise change that was responsible for this significant change in nature. « ${ }^{19}$ Vivekananda's involution argument for panpsychism has great contemporary relevance in this respect, since his unique appeal to the doctrine of the pre-existent effect arguably provides additional support for such genetic arguments.

Now that Vivekananda takes himself to have established the plausibility of panpsychism in general, he goes on to inquire into the precise nature of the all-pervasive consciousness that is »involved « even in primitive matter: »The question is: The involution of what? What was involved? God.« In order to justify his move from panpsychism in general to the specific view that the all-pervasive consciousness is Divine Consciousness (»God «), he presents the following argument:

Argument 2: Vivekananda's Argument for Panentheistic Cosmopsychism

1. Argument from Design: The traditional argument that this universe presents evidence of design makes it reasonable to believe that there exists a divine intelligence.

2. Existence of Mystical Claims: There are credible mystics, such as Sri Ramakrishna, who claim to have directly perceived an all-pervasive Divine Consciousness.

3. Argument for the Epistemic Value of Mystical Experience: Given certain uncontroversial epistemic principles of perceptual justification and

This is Goff's own summary of his argument in Goff 2013. 
perceptual testimony and other relevant premises, it is reasonable for us to believe that the reported spiritual experiences of credible mystics are veridical.

4. Plausibility of Panentheistic Cosmopsychism: Therefore, it is reasonable to believe that there exists an all-pervasive Divine Consciousness. ( from 1-3)

In the long passage cited above, Vivekananda explicitly states premise 1 and the conclusion 4 , and he hints at premise 2 . I will argue that he also implicitly presupposes premise 3 , which he explicitly articulates and defends in detail elsewhere. The fact that he explicitly appeals only to the design argument in this particular passage should not lead us to think that he arrives at the conclusion of panentheistic cosmopsychism on the basis of that argument alone. I will argue that the argument for the epistemic value of mystical experience, which he took to be even stronger than the design argument, is crucial to his argument for panentheistic cosmopsychism.

Vivekananda's first step in establishing the nature of the all-pervasive consciousness is to appeal to the »ancient design « argument (premise 1): the universe displays »intelligence « in its »adjustment of part to part.« He does not present the design argument in all its details, since he assumed that his British audience was familiar with it. Vivekananda's language of »adjustment of part to part « suggests that he likely had in mind William Paley's famous 1802 argument from design. Paley's argument runs as follows. When we inspect a watch, we find that »its several parts are framed and put together for a purpose, e.g. that they are so formed and adjusted as to produce motion, and that motion so regulated as to point out the hour of the day «(Paley 1802: 2). This adjustment of part to part in the watch makes it reasonable to infer that »the watch must have had a maker (Paley 1802: 3). The natural world as a whole resembles the watch in its adjustment of part to part, though on a much vaster scale and with much greater complexity. Therefore, it is reasonable to infer that the natural world was designed by a great and powerful divine intelligence.

Vivekananda's apparently uncritical acceptance of the design argument here is somewhat misleading, since in numerous other lectures, his stance toward the design argument is much more ambivalent, if not critical. For instance, in his lecture on »Vedic Religious Ideals, « he asserts that the design argument »is not a very logical argument, as we all know; there is something childish about it, yet it is the only little bit of anything we can know about God from the external world, that this world required a builder« (CW1:353). Vivekananda's overall position, then, seems to be that while the design argument is not very strong, it does lend some support to the belief that this world 
was designed by a divine intelligence. As I argued in chapter 4, his views on the design argument were likely influenced by John Stuart Mill's ambivalent treatment of the design argument in his Three Essays on Religion (1874). According to Mill (1874: 174), Darwin's theory of evolution through the mechanism of the »survival of the fittest, « if true, »would greatly attenuate the evidence for « a Divine Creator, since it would account for the adjustment of part to part in the natural world in wholly naturalistic terms. However, Mill believed that no one had yet been able to prove that natural selection could explain all instances of apparent design in the natural world. Therefore, he concluded that »in the present state of our knowledge, the adaptations in Nature afford a large balance of probability in favour of creation by intelligence« (Mill 1874: 174). As I already mentioned, Vivekananda, like Mill, partially accepted Darwin's theory of evolution through natural selection, arguing that natural selection can account for the traits of lower animals but cannot explain the moral and spiritual qualities of human beings (CW7:154). Hence, I believe that Vivekananda agreed with Mill in holding that the design argument, though significantly weakened by Darwin's evolutionary theory, still gives us some reason to believe that this world was designed by a divine intelligence.

The next step in Vivekananda's argument is to inquire into the precise nature of this divine intelligence, the existence of which has been made at least somewhat plausible by premise 1 (the argument from design). Premises 2 and 3 comprise Vivekananda's primary argument for believing that the divine intelligence is the all-pervasive Divine Consciousness. Premise 2 is the relatively uncontroversial one that credible mystics like his own guru Sri Ramakrishna claim to have directly experienced the all-pervasive Divine Consciousness. He hints at this premise in the long passage cited earlier when he refers to »the perfect man, « »the God-man « who has realized the Divine Consciousness. At the end of the passage, he also cites Śvetāśvatara Upanișad 4.3 as scriptural support for his panentheistic cosmopsychism: $\gg$ Thou art the man, Thou art the woman ... Thou art everything, O Lord.«Vivekananda looked upon scriptures like the Upanișads as records of the statements of enlightened »Rishis« who directly »realised « certain »supersensuous« facts $\left(\mathrm{CW}_{2}: 60\right)$. For Vivekananda, it was the modern sage Sri Ramakrishna who reaffirmed the panentheistic spiritual vision of these Upanișadic sages. In particular, as we discussed earlier, Sri Ramakrishna claimed to have attained the mystical state of »vijñanna,« which disclosed to him that »everything was Divine Consciousness « Gupta 1992: 345). Sri Ramakrishna specifically taught the young Vivekananda that »there is a state higher than « Advaitic nirvikalpa samādhi, and he described this higher state as the realization that the Lord is »all that exists« (Chetanananda 1997: 36). 
Of course, even if people like Sri Ramakrishna claim to have experienced the all-pervasive Divine Consciousness, what reason do we have to believe them? Vivekananda answers this question in premise 3, the argument for the epistemic value of mystical experience, which he develops in detail in other lectures and writings. Since I discuss this argument in detail in the fifth chapter of my book manuscript in progress, I will only provide here the barest outline of his argument. Vivekananda's key move is to derive a principle of epistemic justification from the traditional Indian doctrine of pratyakșa-pramanna (the perceptual means of knowledge): $»$ What is the proof of God? Direct perception, Pratyaksha. The proof of this wall is that I perceive it « (CW1:415). Here and elsewhere, Vivekananda advances a Principle of Perception as Epistemic Justification (hereafter PEJ), which I would reconstruct as follows:

When a subject $S$ has a perceptual experience which she takes to be of $x, S$ is thereby rationally justified in concluding that she really does experience $x$ unless there are good reasons to think her experience is delusive.

Moreover, Vivekananda defends PEJ by arguing that its denial would leave us »no place to stand on this side of nihilism, « since we presuppose this principle whenever we act on the basis of our sense-perceptual experiences in our day-to-day lives (CW1:199). On the basis of PEJ and other relevant premises, Vivekananda argues that just as we are rationally justified in accepting as real what we perceive through our senses, mystics are rationally justified in accepting as real the transcendental entities such as God or the Ātman which they perceive through supersensuous perception.

But what about those of us who do not enjoy mystical experiences? Is it reasonable for us non-mystics to believe the testimony of mystics? In response to this question, Vivekananda reconceives the traditional Indian doctrine of śabda-pramāna (the testimonial means of knowledge) as a principle of perceptual testimony rooted in PEJ. According to Vivekananda, a credible person's claims about her own »direct perception « count as »direct evidence « for the rest of us (CW1:204-5). I take him to be championing here a Principle of Perceptual Testimony as Epistemic Justification (hereafter PTEJ), which I would formulate as follows:

Others are rationally justified in believing that $S$ 's perceptual experience is as $S$ reports it to be, unless they have some reason to believe that $S$ is deluded or deceiving them.

According to Vivekananda, if we are rationally justified in believing the senseperceptual testimony of ordinary people, then we are also rationally justified 
in believing the testimony of credible mystics like Sri Ramakrishna who claim to have perceived that everything is Divine Consciousness. He concludes, therefore, that the »words« of »Yogis« who »have seen the truth « count as »direct evidence « for the existence of the supersensuous realities they claim to have perceived (CW1:204).

Vivekananda's defense of PEJ and PTEJ resonates strongly with contemporary philosophical defenses of similar epistemic principles, including Richard Swinburne's (2004: 293-326) principles of credulity and testimony, James Pryor's (2000) perceptual dogmatism, and Michael Huemer's (2001) phenomenal conservatism. Moreover, on the basis of these twin epistemic principles, Vivekananda advances an argument for the epistemic value of mystical experience that has remarkable affinities with the »arguments from religious experience« developed by recent philosophers of religion like Swinburne (2004: 293-326), Jerome Gellman (1997), and Kai-Man Kwan (2006).

Premises 1-3, Vivekananda argues, make it reasonable for us to accept panentheistic cosmopsychism, the view that the sole reality is an all-pervasive Divine Consciousness. As he puts it, »Everything that you see, feel, or hear, the whole universe ... is the Lord Himself.... He it is that comes down and becomes the lowest atom, and slowly unfolding His nature, rejoins Himself.«

Notice, then, that the conclusion of Argument 2 specifies the precise nature of the all-pervasive consciousness already established by Argument 1 (the involution argument for panpsychism): namely, that the all-pervasive consciousness is Divine Consciousness. Arguments 1 and 2 are also mutually supportive, since they provide independent grounds for believing that some form of panpsychism is true. Taken together, Arguments 1 and 2, if successful, make it reasonable to believe not only that panpsychism is true but that the most plausible form of panpsychism is panentheistic cosmopsychism. However, from Vivekananda's perspective, in order to achieve absolute certainty of the truth of panentheistic cosmopsychism, we would have to follow in the footsteps of mystics like the Upanișadic sages and Sri Ramakrishna, who attained the direct supersensuous perception of the all-pervading Divine Consciousness through intensive spiritual practice.

Of course, much more would need to be said to clarify and defend fully Vivekananda's panentheistic cosmopsychism. However, I hope to have shown in this chapter that his cosmopsychist position is a sophisticated and original one that deserves to be taken seriously by contemporary philosophers. To conclude, I will summarize four significant advantages of Vivekananda's distinctive cosmopsychist position over rival theories of consciousness. First, by conceiving mind as a subtle form of matter, Vivekananda not only accounts for the causal efficacy of mental states but also welcomes naturalistic explanations 
of a wide range of cognitive phenomena like learning, remembering, and information processing. Second, his cosmopsychist position avoids the subject combination problem, which is the major pitfall for micropsychist theories. Third, since his panentheistic cosmopsychism is based on grounding by manifestation, it is arguably better equipped than other cosmopsychist theories to address various forms of the decombination problem. Fourth, he makes the radical claim that his panentheistic cosmopsychism can be empirically verified through mystical experience. While a small handful of contemporary philosophers have begun to consider the relevance of meditative techniques and mystical experience to debates about consciousness, Vivekananda has gone much further than any of them in defending the epistemic value of mystical experience on the basis of general epistemic principles. For too long, the philosophy of mind has been almost entirely isolated from the philosophy of religion. By bringing these two fields into fruitful dialogue, Vivekananda remains very much our contemporary.

\section{References}

Albahari, M. (2020) »Beyond Cosmopsychism and the Great I Am: How the World Might Be Grounded in Advaitic >Universal Consciousness.« In: Seager (ed.) Routledge Handbook of Panpsychism, 119-30.

Biernacki, L. (2016a) »A Cognitive Science View of Abhinavagupta's Understanding of Consciousness.«Sutra Journal (March 2016). http://www.sutrajournal.com.

Biernacki, L. (2016b) »Connecting Consciousness to Physical Causality: Abhinavagupta's Phenomenology of Subjectivity and Tononi's Integrated Information Theory.« Religions 7, 1-11.

Brown, C.M. (2012) Hindu Perspectives on Evolution. London: Routledge.

Brüntrup, G. and L. Jaskolla, (eds.) (2017) Panpsychism: Contemporary Perspectives. Oxford: Oxford University Press.

Chalmers, D. (1995) »Facing Up to the Problem of Consciousness.« Journal of Consciousness Studies 2.3, 200-19.

Chalmers, D. (1996) The Conscious Mind: In Search of a Fundamental Theory. Oxford: Oxford University Press.

Chalmers, D. (2017) »The Combination Problem for Panpsychism.« In: Brüntrup and Jaskolla (eds.) Panpsychism: Contemporary Perspectives, 179-214.

Chetanananda, S. (1997) God Lived with Them. Kolkata: Advaita Ashrama.

Clifford, W.K. (1874) »Body and Mind.« In: L. Stephen and F. Pollock (eds.) William Kingdon Clifford, Lectures and Essays, vol. 2. London: Macmillan \& Co., 31-70. 
Dasgupta, S. (1922) A History of Indian Philosophy: Volume I. Cambridge: Cambridge University Press.

Duckworth, D. (2017) »The Other Side of Realism: Panpsychism and Yogācāra.« In: S.M. Emmanuel (ed.) Buddhist Philosophy: A Comparative Approach. Hoboken, NJ: Wiley Blackwell, 29-43.

Gasparri, L. (2019) »Priority Cosmopsychism and the Advaita Vedānta.« Philosophy East and West.

Gellman, J. (1997) Experience of God and the Rationality of Theistic Belief. Ithaca, NY: Cornell University Press.

Goff, P. (2013) »Orthodox Property Dualism + Linguistic Theory of Vagueness = Panpsychism.« In: R. Brown (ed.) Consciousness Inside and Out: Phenomenology, Neuroscience, and the Nature of Experience. Dordrecht: Springer, 2013, 75-91.

Goff, P. (2017a) Consciousness and Fundamental Reality. New York: Oxford University Press.

Goff, P. (2017b) »Panpsychism.« In: Stanford Encyclopedia of Philosophy. http://plato. stanford.edu.

Goff, P. (2020) »Cosmopsychism, Micropsychism and the Grounding Relation.«In: Seager (ed.) Routledge Handbook of Panpsychism, 144-156.

Gupta, M. (1992 [1942]) The Gospel of Sri Ramakrishna, trans. Swami Nikhilananda. New York: Ramakrishna-Vedanta Center.

Gupta, M. (2010 [1897-1932]) Śrīśrīrāmakrṣṇakathāmṛta. Kolkata: Udbodhan.

Huemer, M. (2001) Skepticism and the Veil of Perception. Lanham, MD: Rowman \& Littlefield.

James, W. (1950 [189o]) The Principles of Psychology. New York: Henry Holt.

Killingley, D. (1990) »Yogasūtra IV, 2-3 and Vivekānanda's Interpretation of Evolution.« Journal of Indian Philosophy 18, 151-179.

Kwan, K.-M. (2006) »Can Religious Experience Provide Justification for the Belief in God? The Debate in Contemporary Analytic Philosophy.« Philosophy Compass 1(6), 640-61.

Larson, G.J. (1969) Classical Sāṃkhya. Delhi: Motilal Banarsidass.

Levine, J. (1983) »Materialism and Qualia: The Explanatory Gap.«Pacific Philosophical Quarterly 64, 354-61.

Maharaj, A. (2018) Infinite Paths to Infinite Reality: Sri Ramakrishna and Cross-Cultural Philosophy of Religion. New York: Oxford University Press.

Mill, J.S. (1874) Three Essays on Religion. New York: Henry Holt \& Co.

Nagasawa, Y. and Wager, K. (2017) »Panpsychism and Panprotopsychism.« In: Brüntrup and Jaskolla (eds.) Panpsychism: Contemporary Perspectives, 113-129.

Nagel, T. (1974). »What is it like to be a bat?« Philosophical Review 83(4), 435-50.

Nagel, T. (1979) »Panpsychism.«In: T. Nagel, Mortal Questions. Cambridge: Cambridge University Press, 181-95. 
Paley, W. (1802) Natural Theology. Philadelphia: H. Maxwell.

Pryor, J. (2000) »The Skeptic and the Dogmatist.« Nô̂s 34(4), 517-49.

Schaffer, J. (2010) »Monism: The Priority of the Whole, « Philosophical Review 119(1), 31-76.

Seager, W. (ed.) (2020) The Routledge Handbook of Panpsychism. London: Routledge.

Shani, I. (2015) »Cosmopsychism: A Holistic Approach to the Metaphysics of Experience.«Philosophical Papers 44(3), 389-437.

Shani, I. and Keppler, J. (2018) »Beyond Combination: How Cosmic Consciousness Grounds Ordinary Experience.« Journal of the American Philosophical Association 4(3), 390-410.

Swinburne, R. (2004) The Existence of God, second ed. Oxford: Clarendon Press.

Vaidya, A. (2020) »A New Debate on Consciousness: Bringing Classical and Modern Vedānta into Dialogue with Contemporary Analytic Panpsychism.«In: A. Maharaj (ed.) The Bloomsbury Research Handbook of Vedānta. London: Bloomsbury, 393-422.

Vivekananda, S. ([1957-97] 2006-7) The Complete Works of Swami Vivekananda: Mayavati Memorial Edition. 9 vols. Kolkata: Advaita Ashrama. 